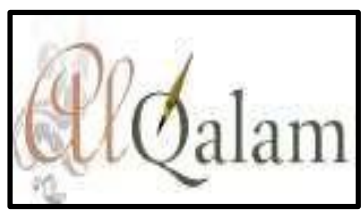

\title{
KODE ETIK GURU DALAM PENGAPLIKASIAN MEDIA PEMBELAJARAN ONLINE PAI DI ERA REVOLUSI INDUSTRI 4.0
}

\author{
Windarto \\ Mahasiswa, Megister Pendidikan Agama Islam, Pasca Sarjana UIN Maulana Malik \\ Ibrahim, Malang \\ Email: owin237@gmail.com
}

\begin{abstract}
Abstrak
Kode etik merupakan pedoman perilaku bagi guru Indonesia, berupa aturan-aturan yang menata hubungan antara; guru dengan lembaga pendidikan, guru dengan guru, guru dengan peserta didik, dan guru dengan lingkungan. Kode etik guru bertujuan menjaga etika dan meningkatkan martabat guru, menjadikan guru handal dalam mengembangkan beragam potensi peserta didik, serta menjunjung tinggi martabat profesi. Penelitian ini berfokus pada kode etik guru dalam ranah profesionalitasnya yang berkewajiban mengembangkan ilmu pengetahuan dan teknologi sesuai UU No. 14 Tahun 2005 tentang guru dan dosen dan keputusan kongres PGRI pasal 2, konkritnya berupa pengaplikasian media pembelajaran berbasis teknologi dan komunikasi di ranah PAI di era revolusi industri 4.0. Metode penelitian ini adalah kualitatif deskriptif dengan pendekatan library research. Sistem pengumpulan data dengan cara mengakomodasi, membaca, mencatat serta mengolah berbagai literatur bacaan. Hasil penelitian menunjukkan bahwa untuk mengukur kode etik guru dalam mengaplikasikan media pembelajaran online PAI di era revolusi industri 4.0 bisa diindikasikan pada; (1) kompetensi pendidik; (2) prinsip pemilihan dan penggunaan media; (3) pembelajaran PAI di era revolusi industri 4.0.
\end{abstract}

\section{Kata kunci: Kode Etik Guru , Media Pembelajaran (online), PAI, Revolusi Industri}

\section{A. PENDAHULUAN}

Dunia pendidikan memberikan amanah yang besar terhadap guru dalam rangka membangun sumber daya manusia yang unggul. Profesi guru sesungguhnya sangat kental dengan upaya mencerdaskan dan menyiapkan bekal kepada peserta didik. Tanggung jawab profesinya tidak gampang, karena pendidikan terbangun melalui proses yang berkelanjutan,

Al Qalam: Jurnal Ilmiah Keagamaan dan Kemasyarakatan Vol. 15, No. 1, Januari-Juni 2021 
Windarto : Kode Etik Guru Dalam Pengaplikasian Media Pembelajaran Online PAI di ERA Revolusi Industri 4.0

penuh syarat, dan beragam tuntutan. Di pundak guru terpikul tugas berupa transfer of knowledge kepada peserta didik, dengan menjunjung tinggi tugas pokoknya, membina dan mengembangkan beragam potensi peserta didik sesuai fitrah secara optimal. Selain itu guru berkewajiban membangun kepribadian peserta didik agar tumbuh dewasa menjadi pribadi yang berbudi pekerti. Sebuah uangkapan mengatakan "guru digugu dan ditiru" menjadi identitas yang mencirikan sosok guru.

Besarnya harapan masyarakat terhadap guru akhirnya memotivasi mereka untuk meningkatkan eksistensi dan perannya. Mengemban profesi guru memerlukan upaya sungguhsungguh dari dalam diri untuk memenuhi standar guru yang kompeten dan berkualitas. Jabatan guru mengantongi banyak tugas, terlebih didalam sekolah dan berikutnya dilingkungan masyarakat. Bukan hanya tentang tugas profesi tetapi menyangkut tugas kemanusiaan dan kemasyarakatan, semuanya memerlukan profesionalitas masing-masing yang meliputi; mendidik, membimbing, mengajar dan melatih. Konsekuensinya guru mengemban banyak peran yang harus terpenuhi diantaranya; sebagai pendidik, pembimbing, pengajar, organisator, mediator, fasilitator, inspirator, supervisor dan seterusnya.

Mengingat peran tersebut, perlu digalakkan pertumbuhan guru baik pertumbuhan pribadi maupun pertumbuhan profesionalitas agar guru senantiasa mengembangkan kapasitas diri, mengikuti atau membaca arus informasi serta mengembangkan ide-ide kreatif dan gagasan inovatif ${ }^{1} \mathrm{Hal}$ ini dimaksudkan agar guru memperhatikan perkembangan zaman, up to date terhadap informasi dan guru memperoleh bekal yang baru sebagai bahan motivasi untuk menciptakan suasana pembelajaran yang adaptif dan lebih menyenangkan bagi siswa.

Piet A. Sahertian mengutip pendapat Lavengeld yang mengatakan guru adalah penceramah zaman. ${ }^{2}$ Guru seharusnya mempunyai landasan ketajaman visi masa depan, sehingga mereka terdorong untuk mengembangkannya. Dalam semangat genealogi Pendidikan Agama Islam (PAI) dikenal "al muhaafadlatu 'ala qodiimi as shoolih wa al akhzu bi al jadiidi al aslah (mempertahankan budaya dan tradisi yang baik dan mengambil kebaruan yang lebih baik).

\footnotetext{
1 Siti Fatimah Soenaryo, "Pembekalan Kemampuan Dasar Mengajar Bagi Calon Dosen Kontrak" (Landasan dan Profesionalisme Dosen di Perguruan Tinggi, Universitas. Muhammadiyah Malang, 2001).

${ }^{2}$ Piet A Sahertian, Konsep Dasar Dan Teknik Supervisi Pendidikan Dalam Rangka Pengembangan Sumber Daya Manusia, (Jakarta: Reneka Cipta, 2000), h. 3.
}

Al Qalam: Jurnal Ilmiah Keagamaan dan Kemasyarakatan Vol. 15, No. 1, Januari-Juni 2021 
Windarto : Kode Etik Guru Dalam Pengaplikasian Media Pembelajaran Online PAI di ERA Revolusi Industri 4.0

Semangat ini menandakan paradigma kontinuitas, berkemajuan, dan berdaptasi dengan perubahan zaman. Untuk merealisasikan visi tersebut, guru berkewajiban terus belajar dan berusaha menjadi guru yang profesional. Aan Hasanah mengajukan tiga syarat kualifikasi guru sehingga dikatakan profesional yaitu; (a) memiliki keahlian yang diajarkan dibidangnya, (b) memiliki integritas dan rasa tanggung jawab yang tinggi, (c) memiliki rasa kesejawatan, menjunjung tinggi kode etik, serta memaknai tugas dan profesinya sebagai karir hidup.

Menarik dikaji, pernyataan Lavengeld yang mengatakan guru adalah penceramah zaman, dimana guru harus memiliki ketajaman visi terhadap masa depan, demikian halnya dalam semangat genealogi Islam. Pemahaman terhadap visi tersebut, tentu berimplikasi pada perubahan paradigma pembelajaran di era revolusi industri 4.0 yang mana sekarang ini bertalian dengan teknologi dan telekomunikasi. Sebagai contoh, perilaku interaksi antara guru dan siswa berubah. Dulu pembelajaran dilakukan tatap muka dikelas, tetapi aktivitas pembelajaran sekarang ini bisa dilakukan secara daring ditempat masing-masing melalui bantuan internet. Dalam paradigma kekinian, pembelajaran dipandang sebagai proses mengelola lingkungan agar siswa belajar sesuai potensi dan kemampuan yang dimiliki. Siswa dinilai sebagai subjek aktif yang harus mencari dan mengkonstruksi informasi.

Revolusi industri 4.0 ini menjelma sebagai peluang sekaligus tantangan bagi guru di dunia pendidikan. Sebagai peluang guru memiliki kans terbaik memunculkan model pembelajaran kreatif dan menyenangkan, seperti mendesain media flash dengan menggunakan model pembelajaran ADDIE. Natalia, Kristin, dan Anugraheni (2019) dalam penelitiannya mengungkap peran guru sebagai pihak yang memfasilitasi pendidikan menjadi sandaran utama, pembelajaran online (e-learning) menjadi orientasi pembelajaran di era reolusi industri 4.0. ${ }^{3}$ Sementara tantangnya lebih mengarah ke problematika profesi guru di Indonesia, satu diantaranya; masih minimnya kualifikasi pendidikan guru dan tenaga kependidikan. Masalah mendasar dunia pendidikan indonesia adalah rendahnya mutu pendidikan, salah satu indikasinya adalah tingkat kelayakan guru. ${ }^{4} \mathrm{Hal}$ ini bisa berarti minimnya ketrampilan atau keahlian guru

\footnotetext{
${ }^{3}$ Putri Ayu Irodah et al., "Revolusi Industri 4.0: Tranformasi Media belajar e-learning menggunakan framework," Irodah et al / Seminar Nasional V 2019 (2019): h. 349.

${ }^{4}$ Siti Irene Astuti Dwiningrum, Desentralisasi dan Partisipasi Masyarakat dalam Pendidikan: Suatu Kajian Teoritis dan Empirik (Yogyakarta: Pustaka Pelajar, 2011), h. 289.
}

Al Qalam: Jurnal Ilmiah Keagamaan dan Kemasyarakatan Vol. 15, No. 1, Januari-Juni 2021 
Windarto : Kode Etik Guru Dalam Pengaplikasian Media Pembelajaran Online PAI di ERA Revolusi Industri 4.0

dalam mendesain pembelajaran termasuk didalamnyya mengaplikasikan media pembelajaran online.

Terlepas dari peluang dan tantangan diatas, ada sebuah hasil penelitian yang menunjukkan penentu kesuksesan pembelajaran dipengaruhi oleh kelengkapan sarana dan media yang dipakai. Semakin beragam media yang dipakai, materi pembelajaran akan semakin mudah diserap oleh peserta didik. Hal ini karena modalitas siswa akan terakomodasi melalui media tersebut. ${ }^{5}$

Atas dasar alasan-alasan diatas kemudian penulis tergugah untuk meneliti tentang bagaimana "kode etik guru dalam pengaplikasian media pembelajaran online PAI di era revolusi industri 4.0 sekarang ini." Mengingat sekarang kita berada di era pendidikan 4.0 yang semuanya berbasis teknologi. Dan satu sisi dalam UU No. 14 Tahun 2005 dan kongres PGRI pasal 2 diatur tentang kode etik dan kewajiban guru berkenaan dengan kredibilitas dan keprofesionalannya.

\section{B. METODE PENELITIAN}

Metode penelitian yang digunakan dalam karya ilmiah ini adalah kualitatif deskriptif melalui pendekatan library research. Sistem pengumpulan data dengan cara mengakomodasi, membaca, mencatat serta mengolah berbagai bahan bacaan yang bersumber dari jurnal, buku referensi, laporan penelitian, skripsi, dll. Dalam penelitian ini, penulis memprioritaskan referensi dari jurnal-jurnal hasil penelitian. Berdasarkan hasil kajian yang mendalam, penulis mencatatat poin-poin penting data penelitian, kemudian membandingkan hasil kajian dari referensi primer jurnal dan referensi sekunder lainnya, dan langkah terakhir adalah menginterpretasikan data kedalam bangunan karya ilmiah ini.

\section{HASIL DAN PEMBAHASAN}

\section{Kode Etik Guru}

Kode etik guru merupakan pedoman perilaku guru Indonesia dalam menajalankan tugas keprofesionalitasan dalam dunia pendidikan. Semakin guru menjunjung tinggi dan mematuhi kode etik tersebut, semakin ia profesional dalam menjalankan profesinya. Kode etik berhubungan erat dengan norma-norma atau etika yang yang dijunjung tinggi dan dipegangi oleh guru.

\footnotetext{
5 Norma Dewi Shalikhah, "Pemanfaatan Aplikasi Lectora Inspire Sebagai Media Pembelajaran Interaktif," Cakrawala: Jurnal Studi Islam 11, no. 1 (June 27, 2016): h. 102, https://doi.org/10.31603/cakrawala.v11i1.105.
}

Al Qalam: Jurnal Ilmiah Keagamaan dan Kemasyarakatan Vol. 15, No. 1, Januari-Juni 2021 
Windarto : Kode Etik Guru Dalam Pengaplikasian Media Pembelajaran Online PAI di ERA Revolusi Industri 4.0

Etik berasal dari kata ethos (Yunani) bermakna adat kebiasaan, cara berfikir, akhlak, sikap, dan watak. ${ }^{6}$ Etika mengandung nilai-nilai yang melandasi perilaku manusia. KBBI mendefinsikan ilmu yang mempelajari atas apa yang baik dan yang buruk, tentang hak dan kewajiban moral. Secara terminologi Sultana mengatakan etika adalah bagian dari filsafat moral yang berkaitan dengan sikap dan perilaku. Menurut Sholichin kode etik sebagai batasan sifat, tabiat, dan tindakan yang secara ideal dapat dikatakan benar atau salah dan baik atau buruk. Tak kalah, Iroegbu dan Adeleke mendefinisikan kode etik sebagai seperangkat prinsip-prinsip dalam suatu organisasi yang dijadikan landasan dalam mengambil keputusan. ${ }^{7}$ Maka disimpulkan bahwa kode etik sangat erat berhubungan dengan perilaku seseorang terhadap profesi yang dijalanan, dalam hal ini profesi keguruan.

Kode etik guru berisi aturan-aturan yang menata hubungan kemanusiaan antara guru dengan lembaga pendidikan, guru dengan guru, guru dengan siswa, dan guru dengan lingkungan. Kode etik guru bertujuan menjaga etika dan meningkatkan martabat guru, menjadikan guru sebagai pendidik yang handal dan mampu mengembangkan seluruh potensi peserta didik. Sebagai sebuah profesi guru membutuhkan kode etik untuk mengatur hubungan-hubungan tersebut. ${ }^{8}$

Undang-Undang Republik Indonesia No. 14 Tahun 2005 mengatur tentang guru dan dosen sebagai berikut: ${ }^{9}$

1. Pasal 20 mengatur kewajiban guru bagian dari tugas keprofesionalan; (a) guru merencanakan, melaksanakan, menilai dan mengevaluasi hasil pembelajaran; (b) guru meningkatkan kualifikasi akademik dan mengembangkan kompetensi secara berkelanjutan sejalan dengan perkembangan ilmu pengetahuan, teknologi, dan seni; (c) guru menjunjung tinggi peraturan perundang-undangan, hukum, kode etik, serta nilainilai agama dan etika

${ }^{6}$ Bayu Purbha Sakti and Universitas Widya Dharma, "Etika Dan Profesi Guru SD Di Tengah Perkembangan Zaman," n.d., h. 102.

${ }^{7}$ Maryanto, "Implementasi Kode Etik Guru Indonesia Dalam Meningkatkan Profesionalisme Guru PPKN Sma Di Kota Semarang," Laporan Penelitian (Semarang: Universitas PGRI Semarang, January 2019), h. 5.

${ }^{8}$ Astuti Dwiningrum, Desentralisasi dan Partisipasi Masyarakat dalam Pendidikan: Suatu Kajian Teoritis dan Empirik, h. 16.

9 “Undang-Undang Republik Indonesia Nomor 14 Tahun 2005 Tentang Guru Dan Dosen,” n.d.

Al Qalam: Jurnal Ilmiah Keagamaan dan Kemasyarakatan

Vol. 15, No. 1, Januari-Juni 2021 
Windarto : Kode Etik Guru Dalam Pengaplikasian Media Pembelajaran Online PAI di ERA Revolusi Industri 4.0

2. Pasal 43; (a) untuk menjaga dan meningkatkan kehormatan dan martabat guru dalam pelaksanaan tugas keprofesionalan, organisasi profesi guru mem bentuk kode etik; (b) kode etik yang dimaksud ayat 1 berisi norma dan etika yang mengikat perilaku guru dalam pelaksanaan tugas keprofesionalan.

Mengenai kewajiban guru terhadap peserta didik diatur pula dikeputusan kongres XXI Persatuan Guru Republik Indonesia Nomor: VI/Kongres/XXI/PGRI/2013 pasal 2 tentang kode etik guru Indonesia; ${ }^{10}$

1. Bertindak profesional dalam melaksanakan tugasnya sebagai pendidik, pengajar, pembimbing, pelatih, dan korektor.

2. Memberikan layanan pembelajaran berdasarkan karakteristik dan perkembangan kejiwaan peserta didik

3. Menciptakan kondisi pembelajaran yang aktif, kreatif, menyenangkan, dan efektif

4. Menghargai martabat peserta didik serta memperlakukannya dengan adil dan objektif

5. Memelihara peserta didik dari semua tindakan yang berpeluang mengganggu perkembangan diri, kesehatan, dan keamanan.

6. Menjaga rahasia pribadi peserta didik.

7. Memelihara hubungan profesional dengan peserta didik.

\section{Media Pembelajaran Online}

Media pembelajaran yang tepat digunakan di era revolusi industri ini adalah media pembelajaran yang berbasis teknologi. Atieka dan Budiana dalam penelitiannya mengungkap pembelajaran konvensional tidak akan mampu membekali kemampuan siswa di era revolusi industri 4.0 ini. ${ }^{11}$ Intervensi teknologi seolah tidak lepas dari perkembangan ilmu pengetahuan, karena teknologi adalah perpaduan yang kompleks antar manusia, mesin, ide, pengelolaan dan lainnya. Dengan bantuan teknologi integrasi ilmu pengetahuan dengan ilmu lain akan terorganisir kedalam tugas-tugas praktis.

\footnotetext{
10 Zherly Nadia Wandi and Nurhafizah Nurhafizah, "Etika Profesi Guru Pendidikan Anak Usia Dini," Golden Age: Jurnal Pendidikan Anak Usia Dini 3, no. 1 (June 27, 2019): h. 38, https://doi.org/10.29313/ga.v3i1.4829.

${ }^{11}$ Irodah et al., "Revolusi Industri 4.0: Tranformasi Media belajar e-learning menggunakan framework," h. 569.
}

Al Qalam: Jurnal Ilmiah Keagamaan dan Kemasyarakatan Vol. 15, No. 1, Januari-Juni 2021 
Windarto : Kode Etik Guru Dalam Pengaplikasian Media Pembelajaran Online PAI di ERA Revolusi Industri 4.0

Media pembelajaran berbasis teknologi dan telekomunikasi terikat dengan penggunaan internet dan aplikasi web. Internet adalah jaringan global kompter di dunia yang memuat berbagai informasi, setiap komputer saling terhubung antara satu negara dengan negara lain. Sehingga internet menjadi teknologi multifungsi yang bisa dimanfaatkan untuk dunia pendidikan. Jadi, media pembelajaran online adalah media pembelajaran jarak jauh yang memungkinkan komunikasi dan interaksi melalui penanan internet. Media pembelajaran ini menggunakan teknologi komputer yang ditunjang oleh sarana telekomunikasi dan multimedia sebagai media inti dalam menyampaikan materi.

Sebutan media pembelajaran yang demikian adalah e-learning atau pembelajaran online. Istilah e-learning berlaku pada sebuah program aplikasi internet yang memuat pelbagai informasi tentang pendidikan yang selalu berkembang, dinamis, dan up to date. Keberadaan $e$ learning dapat menghadirkan pembelajaran dengan kriteria; (a) jaringan memiliki kemampuan untuk memperbaruhi, menyimpan, serta mendistribusikan materi ajar berbasis TIK; (b) pengiriman informasi kepada pengguna jaringan komputer melalui teknologi yang standar; (c) memfokuskan paradigma pembelajaran yang tidak lagi tradisional. ${ }^{12}$

\section{Pendidikan Agama Islam di Era Revolusi Industri 4.0}

Sebutan Revolusi industri diperkenalkan oleh dua tokoh Prancis Friedrich Engel dan Louis Auguste Blanqui di abad ke-19.13 Revolusi Industri adalah suatu perubahan yang berlangsung cepat dalam proses produksi. Revolusi industri fase pertama 1.0 ditandai oleh penemuan mesin uap di Inggris yang menitikberatkan pada mekanisme produksi. ${ }^{14}$ Fase kedua 2.0 dimana produksi terintegrasi, ditandai penemuan listrik yang menggantikan mesin. Fase ketiga 3.0 memasuki fase dimana penemuan mesin yang dapat bergerak dan berpikir secara otomatis yaitu komputer, internet dan telepon genggam. Dan fase keempat 4.0 sekarang ini ditandai dengan pemanfaatan teknologi digital dan informasi sepenuhnya serta keberhasilan

\footnotetext{
${ }^{12}$ Rila Setyaningsih et al., "Penanaman etika komunikasi digital di pesantren melalui pemanfaatan elearning," Jurnal Kajian Komunikasi 8, no. 1 (June 22, 2020): h. 132, https://doi.org/10.24198/jkk.v8i1.24538.

${ }^{13}$ Sigit Priatmoko, "Memperkuat Eksistensi Pendidikan Islam Di Era 4.0” Vol.1 No. 2, no. Ta'lim : Jurnal Studi Pendidikan Islam (July 2018): h. 230.

${ }^{14}$ Almatius Setya Marsudi and Yunus Widjaja, "Industri 4.0 Dan Dampaknya Terhadap Financial Technology Serta Kesiapan Tenaga Kerja Di Indonesia,” Ikraith Ekonomika 2, no. 2 (July 2019): h. 2-3.
}

Al Qalam: Jurnal Ilmiah Keagamaan dan Kemasyarakatan Vol. 15, No. 1, Januari-Juni 2021 
Windarto : Kode Etik Guru Dalam Pengaplikasian Media Pembelajaran Online PAI di ERA Revolusi Industri 4.0

memproduksi digitalisasi, otomatisasi, dan integrasi antara internet dan manufaktur, contohnya muncul sistem transportasi ride-sharing seperti Go-Jek dan Grab. ${ }^{15}$

Perubahan-perubahan produksi yang demikian menyebabkan terjadinya perkembangan besar-besaran pada semua bidang kehidupan mulai dari pertanian, pertambangan, transportasi, teknologi, dan manufaktur yang berdampak mendalam terhadap kondisi sosial, budaya, ekonomi, dan pendidikan. Ciri yang identik adalah dominasi mesin yang menggeser pekerjaan manusia diberbagai lini kehidupan. Istilah ini disebut Disruptive Innovation yang diartikan sebagai fenomena terganggunya pelaku industri lama (incumbent) oleh para pelaku industri baru akibat teknogi informasi. ${ }^{16}$ Implikasinya dikenal istilah pendidikan 4.0 sekarang ini yang mana pendidiksn berbasis teknologi digital (cyber sistem). Konsekuensinya para stake holder atau pemerintah harus memperbaiki mutu pendidikan. Lebih spesifik, perhatian menyangkut konsepkonsep pendidikan, kualifikasi dan kompetensi guru yang unggul, media pembelajaran yang menunjang proses pembelajaran, kurikulum yang repesentatif terhadap kebutuhan pekerjaan, serta fasilitas teknologi yang menunjang proses pembelajaran. ${ }^{17}$

Dalam ranah Pendidikan Agama Islam (PAI) terdjadi istilah Disruptive innovation yang membawa pendidikan Islam kedalam persimpangan jalan. Pemilihan sistem dan bertahan dengan paradigma lama, dimana pendidikan Islam lebih berorientasi pada materi, kurikulum, metode, dan model pembelajaran konvensional. Atau memilih jalan membuka diri dengan menerima era disrupsi dengan segala konsekuensinya, dengan maksud lain memandang Islam bukanlah sebatas mata pelajaran, melainkan Islam menjamah dan memperbaiki konsep-konsep pendidikan. ${ }^{18}$ Lebih jelasnya perbaikan sistem pendidikan, manajemen lembaga pendidikan, manajemen sumberdaya manusia, dan manajemen sarana prasarana. Mengingat tujuan pendidikan Islam adalah hendak meningkatkan dimensi keimanan, penghayatan batin, pemahaman keilmuan dan penalaran intelektual, serta internaliasi nilai-nilai ajaran Islam yang kemudian dipraktekkan dalam kehidupan nyata.

\section{Kode Etik Guru Dalam Pengaplikasian Media Pembelajaran Online Di Era Industri 4.0}

\footnotetext{
15 Priatmoko, “Memperkuat Eksistensi Pendidikan Islam Di Era 4.0,” h. 230.

${ }^{16}$ Priatmoko, h. 230.

17 Dewi Surani, "Studi Literatur: Peran Teknolog Pendidikan Dalam Pendidikan 4.0," Prosiding Seminar Nasional Pendidikan FKIP Universitas Sultan Ageng Tirtayasa Vol. 2 No. 1 (2019): h. 458.

18 Priatmoko, "Memperkuat Eksistensi Pendidikan Islam Di Era 4.0," h. 223.
}

Al Qalam: Jurnal Ilmiah Keagamaan dan Kemasyarakatan Vol. 15, No. 1, Januari-Juni 2021 
Windarto : Kode Etik Guru Dalam Pengaplikasian Media Pembelajaran Online PAI di ERA Revolusi Industri 4.0

Pendidikan yang diminati masyarakat digital di era revolusi industri 4.0 adalah pendidikan berbasis tenologi. Sebagai agen utama, guru harus menjunjung tinggi kode etik apabila ingin bersaing dan tetap eksis dalam pergulatan dunia pendidikan sekarang ini. Pengembangan tersebut berorientasikan pada sumber daya manusia yang profesional, unggul, dan kompeten terhadap tuntutan zaman, dalam hal ini teknologi dan telekomunikasi. Dalam ranah konkritnya, guru bisa mendesain pembelajaran terbarukan, dimana tidak lagi konvensional ditinjau dari strategi, metode dan media yang dipakai.

Salah satu jenis media yang dinilai representatif dalam pendidikan 4.0 adalah media berbaisis teknologi, misalkan saja media bernuansa game kahoot atau media sosial edmodo. Sejalan dengan ini, UU No. 15 Tahun 2005 tentang guru dan dosen Pasal 20 (b) menyatakan bahwa guru wajib meningkatkan kualifikasi akademik dan mengembangkan kompetensi secara berkelanjutan mengikuti perkembangan ilmu pengetahuan, teknologi, dan seni. Oleh sebab itu, perlu kode etik yang menaungi guru secara moral dan profesional. Secara moral mengindahkan etika dan nilai-nilai PAI dan secara profesional menjunjung tinggi keahlian khusus dibidangnya. Maka peneliti memperjelas dan merinci hasil penelitian tentang kode etik guru dalam pengaplikasioan media pembelajaran onine di era revolusi industri 4.0 kedalam tiga pokok bahasan. Ketiganya adalah kompetensi pendidik, prinsip pemilihan dan penggunaan media pembelajran online, dan pembelajaran online di era revolusi industri 4.0.

a. Kompetensi pendidik

Pendidik di era revolusi industri 4.0 dituntut meningkatkan kompetensi guna bersaing di pergulatan Pendidikan 4.0, melihat peserta didik hari ini adalah generasi milenial yang tidak asing dengan teknologi digital. Peserta didik sudah akrab dengan arus teknologi dan informasi dalam kehidupan sehari-hari. Dewi Surani dalam penelitiannya mengungkap ada lima kualifikasi dan kompetensi pendidik yang harus dimiliki di era Pendidika 4.0. Kelimanya meliputi: ${ }^{19}$

1) Kompetensi mendidik, dimana pembelajaran berbasis internet of thing sebagai skil mendasar di era revolusi industri 4.0 ini

${ }^{19}$ Surani, “Studi Literatur: Peran Teknolog Pendidikan Dalam Pendidikan 4.0,” h. 459.

Al Qalam: Jurnal Ilmiah Keagamaan dan Kemasyarakatan

Vol. 15, No. 1, Januari-Juni 2021 
Windarto : Kode Etik Guru Dalam Pengaplikasian Media Pembelajaran Online PAI di ERA Revolusi Industri 4.0

2) Kompetensi komersialisasi teknologi, dimana kompetensi guru bisa membawa siswa memiliki sikap kewirausahaan dengan memanfaatkan teknologi berupa hasil atau inovasi siswa

3) Kompetensi di era globalisasi, dimana dunia tanpa sekat sehingga pendidik harus memiliki wawasan terhadap berbagai budaya, kometensi gobal dan keunggulan untuk memecahkan masalah-masalah pendidikan

4) Kompetensi dalam strategi masa depan, yang mana pendidik harus mempunyai kompetensi untuk memprediksi apa yang akan terjadi di masa depan dan strategi penanganannya dengan mengikuti kuliah, penelitian, sumber daya bersama, mobilitas pegawai, sebagainya.

5) Kompetensi konselor, yang mana pendidik harus menjadi pembimbing konseling bagi siswa, mengingat permasalahannya bukan hanya pada kesulitan memahami materi ajar, tetapi terkait juga masalah psikologis, stres, dan keadaan yang semakin komplek.

b. Prinsip pemilihan dan penggunaan media pembelajaran

Revolusi Industri 4.0 telah berimplikasi nyata pada pembelajaran saat ini, dimana pembelajaran bisa dilakukan secara online dan jarak jauh melalui media digital seperti zoom, google classroom, dan sejenisnya. Kunci keberhasilannya bergantung pada ketepatan guru dalam memilih dan menggunakan media pembelajaran. Aan Hasanah memberikan prinsip-prinsip pemilihan dan penggunaan media pembelajaran yang efektif diantaranya; (1) menganalisis karakteristik kelompok, dengan memperhatikan jenjang pendidikan, latar belakang sosial, ekonomi, pengetahuan, dan ketrampilan awal; (2) merumuskan tujuan pembelajaran; (3) memilih, merancang, memodifikasi serta mengembangkan materi dan media dengan tepat dengan estimasi hemat waktu, tenaga, dan biaya; (4) memanfaatkan materi dan media; (5) mengevaluasi dan meminta tanggapan dari siswa, maksudnya siswa memberikan respon terkait keefektifannya.

Dalam ranah PAI, Dirijen Bimas Islam Kemenag RI memberikan standar literasi media online sebagai berikut: (1) prinsip dalam memproduksi pesan; (2)

Al Qalam: Jurnal Ilmiah Keagamaan dan Kemasyarakatan Vol. 15, No. 1, Januari-Juni 2021 
Windarto : Kode Etik Guru Dalam Pengaplikasian Media Pembelajaran Online PAI di ERA Revolusi Industri 4.0

etika mndistribusikan informasi; (3) menjamin akurasi dan komintmen anti hoak; (4) azaz hikmah dan dakwah; (5) prinsip dalam interaksi virtual .20

c. Pembelajaran PAI di era revolusi Industri 4.0

Pembelajaran PAI sangat berorientasi pada kecerdasan intelektual dan spiritual dalam wujud akhlakul karimah. Pembelajaran PAI saat ini mau tidak mau harus mengikuti trend pendidikan 4.0 dimana pembelajarannya diharuskan akrab dengan internalisasi teknologi dan informasi. Salah satu implementasi nyata adalah pembelajaran online (e-learning) dengan memanfaatkan media kekinian untuk meningkatkan komunikasi interaktif antara pengajar dan pembelajar. Sehingga kualitas pembelajaran diharapkan membaik. Timbul Pardade menyampaikan pembelajaran online (e-leaning) bisa dilakukan guru melalui dua metode yaitu: ${ }^{21}$

1) Synchronous e-learning, adalah pembelajaran yang dilakukan secara real time, dimana guru bisa berkomunikasi dengan siswa secara online pada waktu yang sama ditempat yang berbeda. Misalnya melalui Vidio Conference, chatting, google meet, zoom dll.

2) Asynchronous e-learning, adalah pembelajaran yang dilakukan secara tidak langsung. Sistem pembelajaran melalui aplikasi LMS (Learning Management System) dimana guru menyampaikan materi pembelajaran berupa teks atau audio kemudian siswa meresponnya melalui web atau email pada waktu yang berbeda.

Purbo menambahkan tiga syarat yang harus ada dalam melakukan pembelajaran online (elearning), yaitu;

a. Sederhana, maksudnya siswa mudah memanfaatkan teknologi dan menu yang tersedia, sehingga siswa fokus pada proses pembelajaran bukan pada belajar menggunakan elearning.

b. Personal, maksudnya dalam pembelajaran online guru dapat berinteraksi dengan siswa selayaknya pengajar yang berkomunikasi dengan siwa dikelas.

${ }^{20}$ Setyaningsih et al., "Penanaman etika komunikasi digital di pesantren melalui pemanfaatan elearning," h. 133.

${ }^{21}$ Timbul Pardede, "Pemanfaatan E-Learning Sebagai Media Pembelajaran Pada Pendidikan Tinggi Jarak Jauh,” n.d., h. 5.

Al Qalam: Jurnal Ilmiah Keagamaan dan Kemasyarakatan

Vol. 15, No. 1, Januari-Juni 2021 
Windarto : Kode Etik Guru Dalam Pengaplikasian Media Pembelajaran Online PAI di ERA Revolusi Industri 4.0

c. Cepat, maksudnya ada respon cepat dari guru terhadap keluhan dan kesulitan yang dihadapi oleh siswa.

\section{KESIMPULAN}

Kode etik menjadi pedoman bagi guru Indonesia yang diatur oleh pemerintah dalam UU No. 14 Tahun 2005 tentang Guru dan Dosen dan PGRI pasal 2 tentang kode etik guru Indonesia. Didalamnya memuat norma-norma dan etika yang mengatur hubungan guru dengan lembaga pendidikan; guru dengan sesama guru; guru dengan peserta didik; dan guru dengan lingkungan. Kode etik dibuat bertujuan untuk menjaga dan meningkatkan martabat guru, menjadikan guru sebagai pendidik yang handal dan mampu mengembangkan beragam potensi peserta didik.

Inti pokok dari kewajiban guru dalam kode etik ialah mengembangkan ilmu pengetahuan di era revolusi industri 4.0. Dalam tindakan profesionalnya guru mengaplikasikan media pembelajaran online PAI berbasis teknologi digital. Pada penelitian ini tolok ukur kode etik guru berindikasikan pada; (1) kompetensi pendidik; (2) prinsip pemilihan dan penggunaan media; (3) pembelajaran PAI di era revolusi industri 4.0

\section{E. DAFTAR PUSTAKA}

Astuti Dwiningrum, Siti Irene. Desentralisasi dan Partisipasi Masyarakat dalam Pendidikan: Suatu Kajian Teoritis dan Empirik. Yogyakarta: Pustaka Pelajar, 2011.

Irodah, Putri Ayu, Habibatul Khoiriyah, Zahroil Batul, and Dwi Setyawan. "Revolusi Industri 4.0: Tranformasi Media belajar e-learning menggunakan framework." Irodah et al / Seminar Nasional V 2019 (2019): 10.

Marsudi, Almatius Setya, and Yunus Widjaja. "Industri 4.0 Dan Dampaknya Terhadap Financial Technology Serta Kesiapan Tenaga Kerja Di Indonesia." Ikraith Ekonomika 2, no. 2 (July 2019): 10 .

Maryanto. "Implementasi Kode Etik Guru Indonesia Dalam Meningkatkan Profesionalisme Guru PPKN Sma Di Kota Semarang." Laporan Penelitian. Semarang: Universitas PGRI Semarang, January 2019.

Pardede, Timbul. "Pemanfaatan E-Learning Sebagai Media Pembelajaran Pada Pendidikan Tinggi Jarak Jauh," n.d.

Priatmoko, Sigit. "Memperkuat Eksistensi Pendidikan Islam Di Era 4.0” Vol.1 No. 2, no. Ta'lim : Jurnal Studi Pendidikan Islam (July 2018): 19.

Al Qalam: Jurnal Ilmiah Keagamaan dan Kemasyarakatan

Vol. 15, No. 1, Januari-Juni 2021 
Windarto : Kode Etik Guru Dalam Pengaplikasian Media Pembelajaran Online PAI di ERA Revolusi Industri 4.0

Sahertian, Piet A. Konsep Dasar Dan Teknik Supervisi Pendidikan Dalam Rangka Pengembangan Sumber Daya Manusia,. Jakarta: Reneka Cipta, 2000.

Sakti, Bayu Purbha, and Universitas Widya Dharma. "Etika Dan Profesi Guru SD Di Tengah Perkembangan Zaman," n.d., 9.

Setyaningsih, Rila, Abdullah Abdullah, Edy Prihantoro, and Hustinawaty Hustinawaty. "Penanaman etika komunikasi digital di pesantren melalui pemanfaatan e-learning." Jurnal Kajian Komunikasi 8, no. 1 (June 22, 2020): 128. https://doi.org/10.24198/jkk.v8i1.24538.

Shalikhah, Norma Dewi. "Pemanfaatan Aplikasi Lectora Inspire Sebagai Media Pembelajaran Interaktif." Cakrawala: Jurnal Studi Islam 11, no. 1 (June 27, 2016): 101-15. https://doi.org/10.31603/cakrawala.v11i1.105.

Soenaryo, Siti Fatimah. "Pembekalan Kemampuan Dasar Mengajar Bagi Calon Dosen Kontrak." Universitas. Muhammadiyah Malang, 2001.

Surani, Dewi. "Studi Literatur: Peran Teknolog Pendidikan Dalam Pendidikan 4.0." Prosiding Seminar Nasional Pendidikan FKIP Universitas Sultan Ageng Tirtayasa Vol. 2 No. 1 (2019): 14.

“Undang-Undang Republik Indonesia Nomor 14 Tahun 2005 Tentang Guru Dan Dosen,” n.d.

Wandi, Zherly Nadia, and Nurhafizah Nurhafizah. "Etika Profesi Guru Pendidikan Anak Usia Dini." Golden Age: Jurnal Pendidikan Anak Usia Dini 3, no. 1 (June 27, 2019). https://doi.org/10.29313/ga.v3i1.4829

Al Qalam: Jurnal Ilmiah Keagamaan dan Kemasyarakatan Vol. 15, No. 1, Januari-Juni 2021 